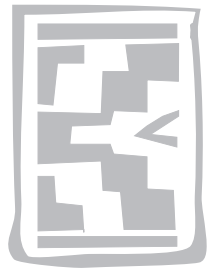

\title{
Relative economic benefits of tactical anthelmintic treatment and urea-molasses block supplementation of Boer goats raised under extensive grazing conditions at Onderstepoort, Pretoria, South Africa
}

\author{
A.F. VATTA ${ }^{1,2 *}$, R.C. KRECEK ${ }^{3}$, R.A. PEARSON ${ }^{4}$, M.F. SMITH ${ }^{5}$, M.O. STENSON ${ }^{1}$, \\ E.F. VAN WIJK ${ }^{1}$ and L.J.S. HARRISON ${ }^{4}$
}

\begin{abstract}
VATTA, A.F., KRECEK, R.C., PEARSON, R.A., SMITH, M.F., STENSON, M.O., VAN WIJK, E.F. \& HARRISON, L.J.S. 2008. Relative economic benefits of tactical anthelmintic treatment and ureamolasses block supplementation of Boer goats raised under extensive grazing conditions at Onderstepoort, Pretoria, South Africa. Onderstepoort Journal of Veterinary Research, 75:237-247

The potential economic benefits of combining tactical anthelmintic treatment for gastrointestinal nematodes and nutritional supplementation with urea-molasses blocks were examined in Boer goats raised under extensive grazing conditions in the summer rainfall area of South Africa. Eight groups of nine goats were monitored over a 12-month period from 1 October 2002 to 9 October 2003. Ad libitum nutritional supplementation with urea-molasses blocks was provided when the goats were housed at night, during the summer (wet season-December 2002 to February 2003), and/or the winter (dry season-June 2003 to August 2003). All the goats were treated symptomatically for Haemonchus contortus infection when deemed necessary by clinical examination of the conjunctiva for anaemia using the $\mathrm{FAMACHA}^{\odot}$ system. Half the groups were tactically treated for gastrointestinal nematodes in mid-summer (28 January 2003). Under the symptomatic treatment, climatic and extensive grazing conditions encountered during the trial, feed supplementation in the winter dry season had the greatest economic benefit and is therefore recommended. Tactical anthelmintic treatment afforded no additional advantage, but the nematode challenge was low.
\end{abstract}

Keywords: Boer goats, extensive grazing, Haemonchus contortus, symptomatic drenching, tactical drenching, urea-molasses blocks

* Author to whom correspondence is to be directed. E-mail: VattaA@arc.agric.za

1 Onderstepoort Veterinary Institute, Private Bag X05, Onderstepoort, 0110 South Africa

2 University of KwaZulu-Natal, Private Bag X01, Scottsville, 3209 South Africa

3 Krecek and Krecek, P.O. Box 12832, Onderstepoort, 0110 South Africa. Present addresses: Ross University School of Veterinary Medicine, St Kitts, West Indies and University of Johannesburg, Johannesburg, South Africa

4 University of Edinburgh, Royal (Dick) School of Veterinary Studies, Division of Veterinary Clinical Science (incorporating Centre for Tropical Veterinary Medicine), Easter Bush Veterinary Centre, Easter Bush, Roslin, Midlothian, Scotland, EH25 9RG United Kingdom

5 Agricultural Research Council, Biometry Unit, Private Bag X519, Silverton, 0127 South Africa

Accepted for publication 28 May 2008-Editor

\section{INTRODUCTION}

Livestock disease caused by gastrointestinal nematodes is considered to have a major impact on the livelihoods of poor livestock keepers (Perry, Randolph, McDermott, Sones \& Thornton 2002). The use of anthelmintics is currently the most common method of parasite control, but the continuing emergence of anthelmintic resistance seriously threatens long-term efficacy. Protein supplementation has been identified as an alternative approach in the management of nematodes (Coop \& Kyriazakis 1999). Therefore, the aim of the current study was to obtain quantitative data on the economic benefits of tactical anthelmintic treatment combined with nutritional supplementation against gastrointestinal 
nematode infections in Boer goats. Here we define tactical anthelmintic treatment as the deworming of an entire flock when a large number of worms are expected, e.g. after good rains at a time when temperature and pasture conditions are ideal for the free-living stages (Van Schalkwyk, Schröder, Malan \& Van Wyk 1995) and symptomatic treatment as the specific treatment of individual animals showing lifethreatening clinical signs of worm infection.

\section{MATERIALS AND METHODS}

\section{Climate data}

The experiment ran from 1 October 2002 to 9 October 2003. Rainfall data were obtained from records kept on the Onderstepoort Veterinary Institute (OVI) experimental farm situated near Pretoria for the years 1991-2003. Temperature data for Pretoria were obtained from the South African Weather Service.

\section{Parasites and infection of goats}

Haemonchus contortus third-stage nematode larvae $\left(L_{3}\right)$ of an anthelmintic-susceptible population (Moredun population) were obtained from the OVI bank of nematode larvae which are preserved in liquid nitrogen. Just prior to use, required numbers of cryopreserved larvae were thawed in lukewarm water. Their motility was checked and their concentration was adjusted to $c .1000 \mathrm{~L}_{3}$ per $\mathrm{m} \ell$ with tap water. They were kept in suspension by agitating their container. The goats were orally infected by slowly depositing the required amount of $L_{3}$ suspension over the base of the tongue with the use of a plastic syringe, to ensure that all the infective larvae would be swallowed.

\section{Animal maintenance}

Seventy-two 5 to 6-months-old male Boer goats were purchased from the Kuruman district, Northern Cape Province, South Africa and transported to the OVI near Pretoria in two batches during June and July 2002. They were housed in pens with concrete floors, which were cleaned daily from Monday to Friday. Intact goats were castrated. All were fed a commercial pelleted feed and hay and water ad libitum.

The animals were dewormed and artificially re-infected with $H$. contortus as set out in Table 1.

On 26 August 2002, the animals were moved to the OVI experimental farm "Kaalplaas", where they grazed extensively in a paddock of $c .110$ ha of mixed grazing and browse. The pasture had apparently not been grazed by small ruminants for 6 years prior to the current study, but had been used for the grazing of cattle, which shared the paddock with a small number of impalas (Aepyceros melampus), common duikers (Sylvicapra grimmia), steenbok (Raphicerus campestris) and warthog (Phacocherus aethiopicus). The cattle were removed from the paddock before the start of the experiment.

\section{Experimental design and monitoring}

On 1 October 2002 the goats were allocated to eight groups each comprising nine animals (Table 2). The groups were balanced for live mass. This was done as follows: the goats were ranked in terms of live mass from highest to lowest live mass as determined on 25 September 2002. The eight goats with the highest live masses were then each randomly allocated to a group. The next eight goats were similarly randomly allocated to a group. This process was followed until all the goats had been allocated to a group. The goats were housed in sheds per feed group at night when urea-molasses block supplementation [Voermol Protein Blocks, Maidstone, South Africa; urea $67 \mathrm{~g} / \mathrm{kg}$ dry matter (DM)] was provided ad libitum to the supplemented groups during the appropriate periods. About $10 \mathrm{~kg}$ of a commercially prepared pelleted feed (crude protein $174 \mathrm{~g} / \mathrm{kg} \mathrm{DM}$ ) was scattered in the feed troughs each evening to lure the animals back into the sheds and its effect on the animals' nutrition was considered negligible. The goats were monitored throughout the experimental period and on 28 January 2003 some were either treated tactically with $0.4 \mathrm{mg} / \mathrm{kg}$ ivermectin administered orally, while others were not.

The goats were examined for anaemia according to the FAMACHAC system on a weekly basis (Vatta, Letty, Van der Linde, Van Wijk, Hansen \& Krecek 2001). The FAMACHAC system allows an animal's mucous membrane colour to be classed into one of five colour categories, from 1 (non-anaemic) to 5 (severely anaemic). Symptomatic anthelmintic treatments with ivermectin (Ivomec Liquid ${ }^{\mathrm{TM}}$, Merial South Africa, $0.4 \mathrm{mg} / \mathrm{kg}$ ) were given orally to those animals scored in Categories 3, 4 or 5, as these levels of anaemia are considered to be life-threatening.

On the same day that the goats were examined clinically for anaemia, they were weighed and scored for body condition. Faecal samples were collected to determine nematode egg counts (Reinecke 1983) and faecal cultures were prepared in order that differential third-stage nematode larval counts could 
TABLE 1 Anthelmintic treatments administered to experimental Boer goats prior to artificial infection with Haemonchus contortus in preparation for the experiment

\begin{tabular}{|c|c|c|}
\hline Date & Time of day & Treatment \\
\hline $\begin{array}{l}17 \text { July } 2002 \\
18 \text { July } 2002 \\
18 \text { July } 2002 \\
19 \text { July } 2002 \\
30 \text { or } 31 \text { July } 2002 \\
7-13 \text { August } 2002 \\
19 \text { August } 2002 \\
23 \text { August } 2002 \\
26 \text { August } 2002\end{array}$ & $\begin{array}{l}\text { Morning } \\
\text { Morning } \\
\text { Afternoon } \\
\text { Morning } \\
\text { Morning }\end{array}$ & $\begin{array}{l}7.5 \mathrm{mg} / \mathrm{kg} \text { oxfendazole (Oxfen } \\
5.0 \mathrm{mg} / \mathrm{kg} \text { oxfendazole (Oxfen Bayer Animal Health) } \\
5.0 \mathrm{mg} / \mathrm{kg} \text { oxfendazole (Oxfen }{ }^{\mathrm{TM}} \text {, Bayer Animal Health) } \\
12.0 \mathrm{mg} / \mathrm{kg} \text { levamisole (Tramisol }{ }^{\mathrm{TM}} \text {, Intervet) } \\
\text { Faecal flotations }{ }^{\mathrm{a}} \text { positive for } 23 \text { of } 72 \text { goats } \\
0.4 \mathrm{mg} / \mathrm{kg} \text { ivermectin (Ivomec Liquid } \\
\text { Faecal flotations negative for all goats } \\
\text { Infection with } c .3000 \text { third-stage larvae of Haemonchus contortus } \\
\text { Transfer to experimental paddocks }\end{array}$ \\
\hline
\end{tabular}

a Flat-sided medicine bottle flotation method (Reinecke 1983)

TABLE 2 A comparison of the market value per goat corrected as applicable for the costs of supplementation with urea-molasses blocks and tactical ivermectin treatment for gastrointestinal nematodes for eight groups of nine Boer goats. Each group was either tactically treated on 28 January $2003(+)$ or not $(-)$. All the goats were treated symptomatically with ivermectin as and when required. Supplementation with urea-molasses blocks was either not given or given in the dry winter season (June to August 2003), the wet summer season (December 2002 to February 2003), or both periods

\begin{tabular}{|l|l|l|l|l|l|l|l|l|}
\hline Group & $\begin{array}{l}\text { Time of urea- } \\
\text { molasses block } \\
\text { supplementation }\end{array}$ & $\begin{array}{l}\text { Tactical } \\
\text { ivermectin } \\
\text { treatment }\end{array}$ & $\begin{array}{l}\text { Mean } \\
\text { dressed- } \\
\text { out } \\
\text { carcass } \\
\text { mass(kg) }\end{array}$ & $\begin{array}{l}\text { Market } \\
\text { value }\end{array}$ & $\begin{array}{l}\text { Cost of } \\
\text { urea- } \\
\text { molasses } \\
\text { blocks per } \\
\text { animal }\end{array}$ & $\begin{array}{l}\text { Cost of } \\
\text { ivermectin } \\
\text { treatment } \\
\text { per animal }\end{array}$ & $\begin{array}{l}\text { Mean net } \\
\text { value per } \\
\text { animal }\end{array}$ & $\begin{array}{l}\text { Net } \\
\text { benefit } \\
\text { over } \\
\text { Group 1 } \\
\text { controls }\end{array}$ \\
\hline 1 & Unsupplemented & - & 25.0 & 54.98 & 0 & 0 & 54.98 & 0 \\
2 & Unsupplemented & + & 24.4 & 53.61 & 0 & 0.69 & 52.92 & -2.06 \\
3 & Dry season & - & 27.6 & 60.79 & 2.51 & 0 & 58.28 & 3.30 \\
4 & Dry season & + & 25.1 & 55.13 & 2.51 & 0.68 & 51.94 & -3.04 \\
5 & Wet season & - & 23.1 & 50.91 & 2.15 & 0 & 48.76 & -6.22 \\
6 & Wet season & + & 23.5 & 51.68 & 2.15 & 0.69 & 48.84 & -6.14 \\
7 & Wet-and-dry & - & 23.8 & 52.43 & 4.66 & 0 & 47.77 & -7.21 \\
8 & seasons & & 25.4 & 55.79 & 4.66 & 0.71 & 50.42 & -4.56 \\
\end{tabular}

All prices are stated in US\$. (US\$ 1.00 was approximately equal to R7.00 in January 2004)

a The market value of the carcass was estimated at US\$2.20/kg

be made (Reinecke 1983; Van Wyk, Cabaret \& Michael 2004). However, the infective larvae of Teladorsagia and Trichostrongylus spp. were not differentiated. Blood was collected in tubes containing EDTA (Vacutainer ${ }^{\mathrm{TM}}$ tubes, Becton Dickinson, France) for haematocrit determination (Vatta 2001) and in tubes for serum analyses for total protein, albumin and urea. Serum total protein, albumin and urea were determined by means of colorimetric methods utilizing reflectance spectrophotometry (Vitros ${ }^{\mathrm{TM}}$, Johnson and Johnson Clinical Diagnostics).

The study ran until 9 October 2003, when the animals were slaughtered, their dressed-out carcass masses determined and their nematodes recovered from the abomasum, small intestine, caecum and colon, following the methods of Van Wyk, Schröder, Van Schalkwyk \& Horak (1987); Visser, Van Wyk \&
Alves (1987); Wood, Amaral, Bairden, Duncan, Kassai, Malone, Pankavich, Reinecke, Slocombe, Taylor \& Vercruysse (1995).

\section{Economic analysis}

The most economically viable experimental treatment was determined by cost-benefit analysis (Table 2). The mean cold dressed-out carcass mass was determined for each group of goats and was multiplied by US $\$ 2.20 / \mathrm{kg}$, the market value per kilogram of meat at slaughter, to give the mean market value per carcass for each group. The calculation of the cost of urea-molasses block supplementation per goat was based on the amount of urea-molasses block consumed per goat per group, where applicable, and the cost of a urea-molasses block at purchase. This assumed that each goat consumed 
the same amount of block, which is not usually the case. The cost of the tactical treatment per goat, where applicable, was calculated by determining the average amount of anthelmintic drenched per goat for that group and multiplying this value by the cost of anthelmintic at purchase. The costs of block supplementation and tactical treatment were then subtracted from the mean market value per carcass where applicable, and the corrected carcass value subtracted from the mean market value per carcass for Group 1. The resultant value indicated an increase or decrease in carcass value relative to Group 1.

\section{Herbage sampling}

With the exception of the week of 23-29 December 2002, herbage samples were collected weekly from 31 October 2002 to 2 October 2003. These were collected by cutting or plucking the grass and herbs falling within a quadrat of $400 \mathrm{~mm} \times 400 \mathrm{~mm}$ thrown at random on ten occasions during a walk-about [the method having been modified from that described by Smith (1999) for sward sampling]. The walk-about took the form of a route in the shape of a "W", "X" or variation thereof within the paddocks grazed by the goats and was similar to the collecting route described by Hansen \& Perry (1994) for isolating infective larvae from herbage. Six different routes were followed in rotation. During each walkabout, samples of browse leaves were also collected from shrubs falling within c. $3 \mathrm{~m}$ of the place where the quadrat fell. The samples were air-dried, coarsely milled to a diameter of $c .10 \mathrm{~mm}$ before being further milled through a $1 \mathrm{~mm}$ sieve in the labo- ratory and analyzed for dry matter (Harris 1970), ash (Harris 1970), acid detergent fibre (Goering \& Van Soest 1970) and neutral detergent fibre (Robertson \& Van Soest 1981). Crude protein content was determined by the Dumas combustion method, using the Leco FP-2000 instrument (Leco Corporation, St Joseph, Michigan, USA).

\section{Data handling and analysis}

The data were analysed statistically by means of a $2 \times 4$ factorial analysis of variance, testing both the main effects of tactical anthelmintic treatment and supplementary feeding and the treatment by feeding interaction. Means were separated using Fisher's protected t-test least significant difference (LSD) at the $5 \%$ level. All data were analysed using the GenStat statistical system (GenStat ${ }^{2}$ for Windows ${ }^{\mathrm{TM}}, 7^{\text {th }}$ edition, VSN International Ltd). The data for the faecal egg counts and worm counts were $\log _{10}$-transformed for analysis to stabilize variances but the untransformed data are presented in the figures.

\section{RESULTS}

\section{Rainfall and temperature}

For the purposes of this experiment, summer is defined as running from 1 December to 28 February and winter from 1 June to 31 August. It was unusually dry in November 2002 (Fig. 1) and there was no rainfall from April to September 2003.

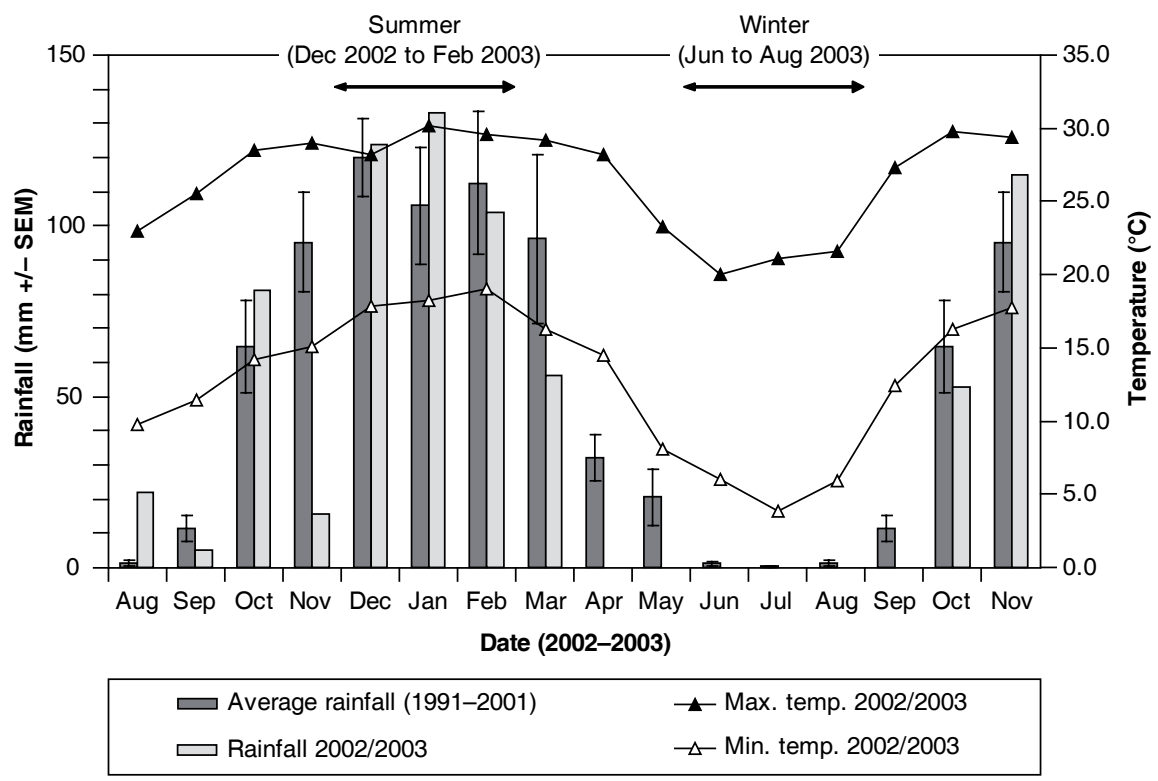

FIG. 1

The rainfall (compared with the average for 1991-2001 \pm the standard error of the mean) and temperature data for the OVI experimental farm during the experimental period 


\section{Herbage analysis}

The average composition of the herbage samples collected throughout the period of the experiment is given in Table 3. The dry matter content of the herbage was lowest during the period of summer rainfall and increased in the dry winter season (Table 4). The crude protein content of the herbage was highest in the rainy season and decreased as the grazing matured (Table 4). The acid detergent fibre and neutral detergent fibre content remained relatively consistent throughout the period of the experiment (data not shown).

\section{Consumption of blocks}

The consumption of block per goat per day for the wet-summer-season-supplementation period was estimated at $54 \mathrm{~g}$ (wet-season-supplemented group) and $62 \mathrm{~g}$ (wet-and-dry-season-supplemented group). During the dry winter season, the consumption per goat per day was $78 \mathrm{~g}$ (dry-season-supplemented group) and $77 \mathrm{~g}$ (wet-and-dry-season-supplemented group). The intake of block was lower than the man- ufacturer's recommended daily intake of 100-140 g per sheep per day (Voermol Pasture Supplements Product Handbook, $2^{\text {nd }}$ edition, Voermol, Maidstone, South Africa).

\section{Parasitological findings}

While the goats were infected with $H$. contortus (Fig. 2), the egg counts were low throughout the study [< 400 eggs per gram of faeces (epg)]. Before tactical treatment, there were no statistically significant differences in mean egg counts between tactically and non-tactically treated groups. The tactical treatment was effective $(P<0.001)$, with the mean egg count dropping to almost zero in the tactically treated groups. There were generally no statistically significant differences between mean egg counts for the feed groups. After May 2003, all the groups had very low egg counts $(<150 \mathrm{epg})$.

Third-stage larvae of Haemonchus spp. predominated in the faecal cultures from October 2002 to March 2003. During April and May 2003 larvae of Haemonchus and Teladorsagia/Trichostrongylus

TABLE 3 Average composition of herbage sampled weekly from 31 October 2002 to 2 October 2003 in the paddocks where the goats were grazed for the experiment

\begin{tabular}{|l|l|l|l|l|l|l|}
\hline $\begin{array}{l}\text { Herbage } \\
\text { samples }\end{array}$ & $\begin{array}{l}\text { Dry matter } \\
\mathbf{( g / k g )}\end{array}$ & $\begin{array}{l}\text { Moisture } \\
\text { content } \mathbf{( g / k g )}\end{array}$ & $\begin{array}{l}\text { Crude protein } \\
\text { (g/kg DM) }\end{array}$ & $\begin{array}{l}\text { ADF } \\
\text { (g/kg DM) }\end{array}$ & $\begin{array}{l}\text { NDF } \\
\text { (g/kg DM) }\end{array}$ & $\begin{array}{l}\text { Ash } \\
\text { (g/kg DM) }\end{array}$ \\
\hline Mean & 578 & 422 & 69 & 361 & 592 & 101 \\
SD & 122 & 122 & 15 & 24 & 42 & 12 \\
SEM & 18 & 18 & 2 & 4 & 6 & 2 \\
Minimum & 328 & 207 & 45 & 307 & 508 & 81 \\
Maximum & 793 & 672 & 107 & 409 & 666 & 139 \\
$n$ & 48 & 48 & 48 & 48 & 48 & 47 \\
\hline
\end{tabular}

$\mathrm{SD}=$ standard deviation

$\mathrm{SE}=$ standard error of the mean

$\mathrm{DM}=$ dry matter

ADF $=$ acid detergent fibre

$\mathrm{NDF}=$ neutral detergent fibre

TABLE 4 Seasonal mean pasture dry matter (DM), pasture crude protein (CP), body condition score, total serum protein, serum albumin, serum urea and haematocrit for spring 2002 (1 October to 30 November 2002), summer 2002/03 (1 December 2002 to 28 February 2003), autumn (1 March to 31 May 2003), winter (1 June to 31 August 2003) and spring 2003 (1 September to 9 October 2003)

\begin{tabular}{|l|l|l|l|l|l|}
\hline Season & $\begin{array}{l}\text { Spring } \\
\mathbf{2 0 0 2}\end{array}$ & $\begin{array}{l}\text { Summer } \\
\mathbf{2 0 0 2 / 0 3}\end{array}$ & $\begin{array}{l}\text { Autumn } \\
\mathbf{2 0 0 3}\end{array}$ & $\begin{array}{l}\text { Winter } \\
\mathbf{2 0 0 3}\end{array}$ & $\begin{array}{l}\text { Spring } \\
\mathbf{2 0 0 3}\end{array}$ \\
\hline Mean pasture DM \pm SD (g/kg) & $519.4 \pm 75.1$ & $461.9 \pm 70.9$ & $551.2 \pm 99.9$ & $708.7 \pm 49.9$ & $649.8 \pm 99.3$ \\
Mean pasture CP \pm SD (g/kg DM) & $75.6 \pm 9.3$ & $81.9 \pm 10.0$ & $67.6 \pm 9.0$ & $54.1 \pm 9.2$ & $72.0 \pm 19.9$ \\
Mean body condition score \pm SD & $2.0 \pm 0.3$ & $2.6 \pm 0.4$ & $3.3 \pm 0.5$ & $3.1 \pm 0.5$ & $2.8 \pm 0.5$ \\
Mean total serum protein \pm SD (g/l) & $63.5 \pm 3.4$ & $65.2 \pm 3.2$ & $64.4 \pm 3.4$ & $64.6 \pm 4.1$ & $64.3 \pm 3.2$ \\
Mean serum albumin \pm SD (g/l) & $24.9 \pm 1.9$ & $26.3 \pm 2.1$ & $27.1 \pm 2.5$ & $25.1 \pm 1.9$ & $26.1 \pm 1.8$ \\
Mean serum urea \pm SD (mmol/l) & $5.55 \pm 1.23$ & $5.91 \pm 1.41$ & $4.71 \pm 1.32$ & $2.59 \pm 1.01$ & $2.06 \pm 0.61$ \\
Mean haematocrit \pm SD (\%) & $23.8 \pm 2.1$ & $24.2 \pm 2.3$ & $25.3 \pm 2.3$ & $25.5 \pm 2.4$ & $25.2 \pm 2.2$ \\
\hline
\end{tabular}

$\mathrm{SD}=$ standard deviation 


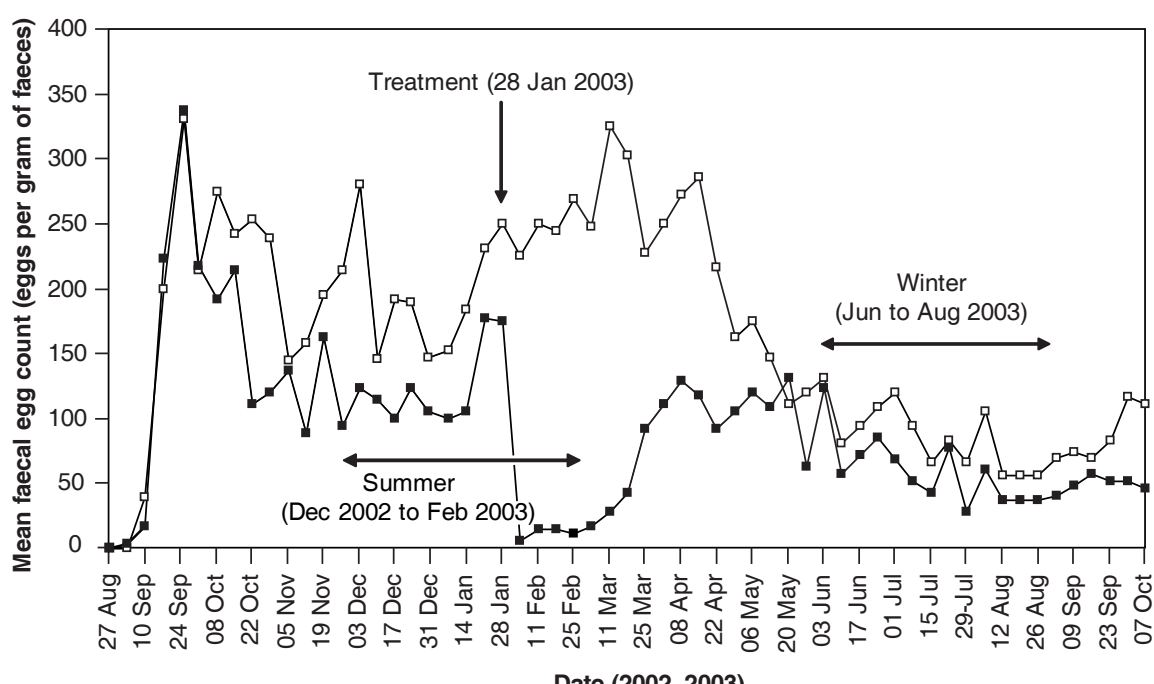

Date (2002-2003)

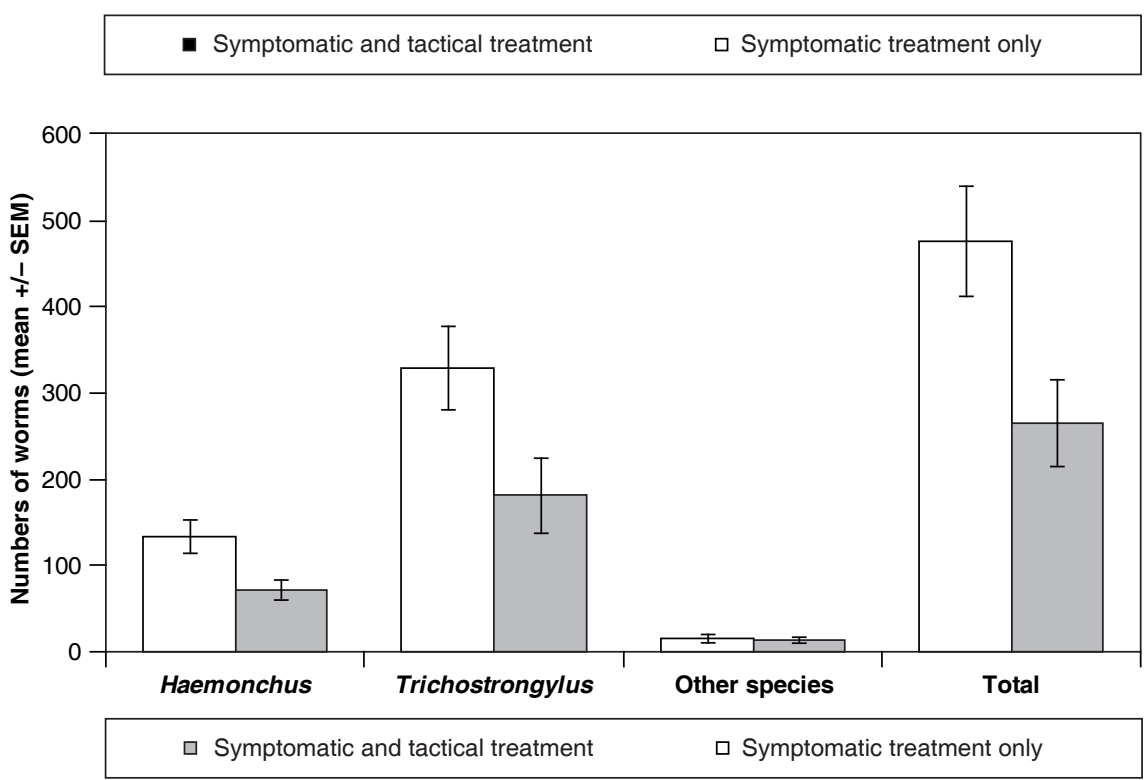

FIG. 2

Faecal egg counts (eggs per gram, $\mathrm{epg}$ ) for the 36 Boer goats treated tactically and symptomatically $(\mathbf{-})$ with ivermectin compared to the 36 goats given symptomatic treatment only (ㅁ)

\section{FIG. 3}

Mean worm counts $( \pm$ standard error of the mean) for the 36 Boer goats treated tactically and symptomatically with the anthelmintic ivermectin (shaded columns) compared to the 36 goats given symptomatic treatment only (nonshaded columns) spp. occurred in approximately equal numbers in the cultures, while from June to October 2003 larvae of Teladorsagia/Trichostrongylus spp. were predominant (data not shown). Larvae of Oesophagostomum spp. were found in very low numbers in the cultures during one week in December 2003.

As judged by the nematodes recovered following the slaughter of the goats, Trichostrongylus spp. were most abundant, followed by Haemonchus spp. and other species (Fig. 3). Of the Trichostrongylus spp., $T$. falculatus was the most common and only limited numbers of $T$. axei and $T$. colubriformis were recorded. The other species identified included small numbers of Teladorsagia spp., Strongyloides papillosus, Impalaia tuberculata, Trichuris spp. and Oesophagostomum spp. (on average, 14 nematodes of these other species). There were significant differences between the tactically and non-tactically treated goats for Haemonchus spp. counts, Trichostrongylus spp. counts and total counts $(P<0.05)$, but there were no significant differences between feed groups $(P>0.05)$.

\section{Production parameters}

With the exception of 11 March 2003, there were no significant differences in mean live mass between the tactically and non-tactically treated groups. Although the worm burdens between the tactically and non-tactically treated goats were significantly different $(P<0.05)$, there were never any statistically significant differences in the live mass gain $(P>0.05)$, in the body condition scores $(P>0.05)$ or in the cold dressed-out carcass masses $(P>0.05)$ between the tactically and non-tactically treated 


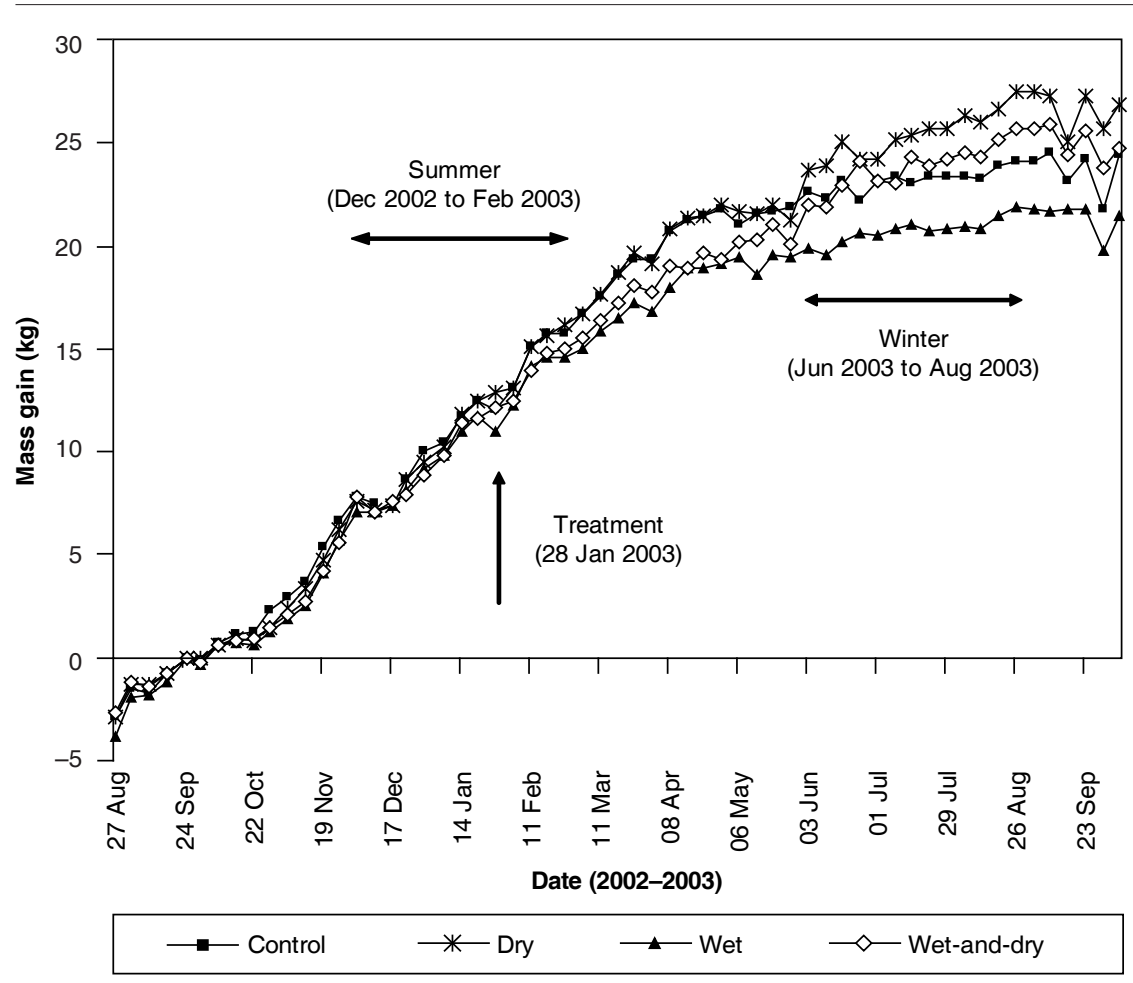

FIG. 4

Mass gains for the four different feed groups of 18 Boer goats each. One group received no urea-molasses block supplementation (Control, $\mathbf{\varpi})$, a second group received urea-molasses block supplementation in the summer (Wet, $\Delta)$, a third group received urea-molasses block supplementation in the winter (Dry, $*$ ) and a fourth group received urea-molasses block supplementation in the summer and winter (Wet-anddry, $\diamond)$

groups (data not shown). Therefore, the gastrointestinal parasites had no significant effect on the production parameters of the goats.

The dry-season-supplemented goats showed the greatest live mass gain overall (Fig. 4). From the end of July 2003 until the end of the experiment, the differences in mass gain by date between the controls and the dry-season-supplemented goats were generally significant $(P<0.05)$. The mass gains by date for the wet-and-dry-season-supplemented goats were higher than those of the controls but lower than those of the dry-season-supplemented goats during this period and the differences were not significant. The wet-season supplemented goats had lower mass gains than the controls but the differences were also not significant.

Body condition improved during the wet season and was highest in the mid-autumn period, but declined slightly during the dry winter (Fig. 5). When the feed groups were compared, the body condition scores of the dry-season-supplemented and the wet-anddry-season-supplemented groups were significantly higher than the scores of the controls on several occasions from, respectively, mid-December and midFebruary onwards $(P<0.05)$.

\section{Anaemia levels and clinical biochemistry}

Throughout the study period, the seasonal mean haematocrits were in the range of $23.8-25.5 \%$
(Table 4) thus remaining within, but at the lower end of the normal haematocrit range for goats of 22$38 \%$ (Feldman, Zinkl \& Jain 2000). Notably, the mean haematocrit readings were at their lowest when Haemonchus spp. were predominant, i.e. spring/summer 2002/2003 (Table 4 and Fig. 2). Any statistically significant differences between supplemented groups and controls and between tactically and non-tactically treated groups were always less than three percentage points and were considered clinically marginal as at no time did the mean of any of these groups fall below $22 \%$ (data not shown). The mean FAMACHAC scores for the groups were lower than 2.4 on all occasions and closely mirrored the trend in haematocrits (data not shown). Individual goats were treated as their FAMACHAC scores were " 3 " or " 4 ", but no scores of " 5 " were recorded and only on four occasions were goats scored as "4". There were no significant differences between experimental groups in the average number of days on which goats received treatment for various conditions (including symptomatic treatment according to the FAMACHAC system) (Table 5).

The mean serum total protein values calculated for the goats in total remained within the normal reference range of 55.4-71.8 $\mathrm{g} / \ell$ (Johann Muller, personal communication 2002) and generally at a level of $64.4 \mathrm{~g} / \ell$ (Table 4 ). The overall mean serum albumin values also remained within the normal reference range of $20.1-29.4 \mathrm{~g} / \mathrm{l}$ and generally at a level 


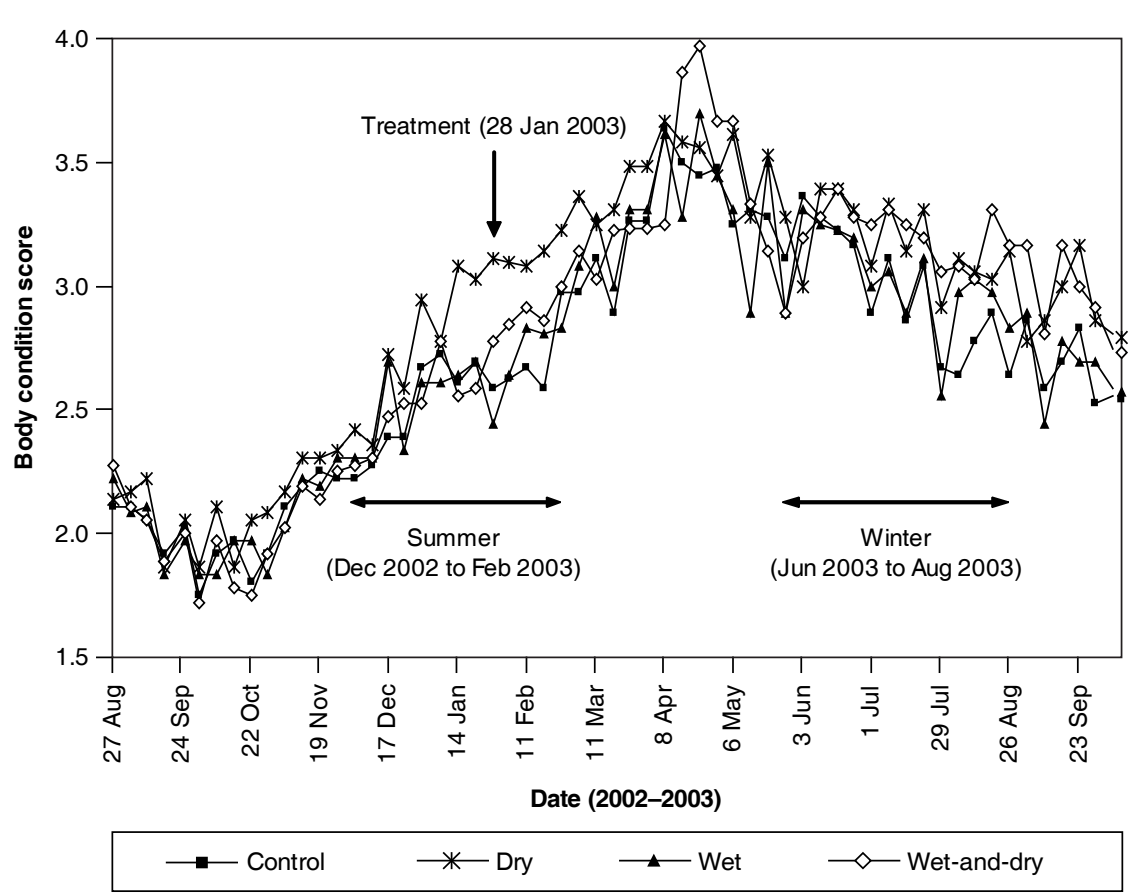

FIG. 5

Body condition scores for the four different feed groups of 18 Boer goats. One group received no urea-molasses block supplementation (Control, $\mathbf{m})$, a second group received urea-molasses block supplementation in the summer (Wet, $\mathbf{\Lambda})$, a third group received ureamolasses block supplementation in the winter (Dry, *) and a fourth group received urea-molasses block supplementation in the summer and winter (Wet-and-dry, $\diamond$ ). Data for 4 February, 25 March and 1 April 2003 were not obtained and the values shown are averages between the available values immediately before and after the missing values

TABLE 5 Problems noted in the four feed groups of experimental goats. Each value represents the average number of days over the study period for which goats within each group were treated for a particular problem

\begin{tabular}{|c|c|c|c|c|}
\hline \multirow{2}{*}{ Problem } & \multicolumn{4}{|c|}{ Treatment } \\
\hline & Control & Dry & Wet & Wet-and-dry \\
\hline Respiratory tract infections & 0.7 & 0.2 & 0.7 & 0.6 \\
\hline Coccidiosis and diarrhoea & 0.1 & 0.9 & 0.2 & 0.2 \\
\hline Abscesses & 6.6 & 7.1 & 5.1 & 3.0 \\
\hline Joint problems/ lameness & 1.8 & 0.2 & 1.1 & 3.7 \\
\hline Anaemia (FAMACHA@ 3 or 4 ; treated) & 1.3 & 0.6 & 0.9 & 1.5 \\
\hline Eye infections & 0.1 & 0.2 & 0.1 & 0.7 \\
\hline Other problems (e.g. wounds, ticks) & 0.4 & 0.8 & 0.0 & 0.3 \\
\hline Total & 10.6 & 9.6 & 7.9 & 9.6 \\
\hline
\end{tabular}

Dry $\quad=$ dry-season supplementation

Wet $\quad=$ wet-season supplementation

Wet-and-dry = wet-and-dry-season supplementation

of $25.9 \mathrm{~g} /$. Any statistically significant differences between supplemented groups and controls and between tactically and non-tactically treated groups were always less than $4 \mathrm{~g} / \ell$ for serum total protein and $3 \mathrm{~g} / \ell$ for serum albumin. The differences were considered clinically marginal as, with only a few exceptions when the means for albumin approached $30 \mathrm{~g} / \ell$, the means were within the normal reference ranges. From October 2002 to the end of February 2003 the overall mean serum urea values were $c$. $5.77 \mathrm{mmol} / \ell$, with highest levels in the summer. However, from March 2003 onwards, the mean value declined to $c$. $3.35 \mathrm{mmol} / \ell$, which was below the normal range of $4.62-9.62 \mathrm{mmol} / \ell$. Any statistically significant differences in urea levels between sup- plemented groups and controls and between tactically and non-tactically treated groups were again considered clinically marginal (maximum difference: $1.10 \mathrm{mmol} / \ell$ ), most of these differences occurring during the latter half of the study when the urea levels were low in all the goats.

\section{Economic analysis}

Although the difference was not significant at the $5 \%$ level, at the $10 \%$ level the mean cold dressedout carcass mass of the winter dry-season-supplemented group $(26.4 \mathrm{~kg}$ ) was statistically significantly greater than that of the control group $(24.7 \mathrm{~kg})$. The wet-season-supplemented group had the lowest 
mean dressed-out carcass mass $(23.3 \mathrm{~kg})$, while the mean carcass mass of the wet-and-dry-seasonsupplemented group was similar to that of the control group $(24.6 \mathrm{~kg})$. When the cost-benefit analysis was carried out, and the cost of tactical drug treatment and urea-molasses block supplementation considered, only winter dry-season supplementation without tactical treatment (Group 3) proved economically viable.

\section{DISCUSSION}

The occurrence of larvae of Haemonchus during October to March and larvae of Teladorsagia/Trichostrongylus during June to October agrees with the results of previously published studies on the occurrence of these parasites in sheep and goats in the summer rainfall area of South Africa (Horak \& Louw 1977; Horak 1978; Boomker, Horak \& Ramsay 1994). The origin of the other species was probably from the cattle which had previously grazed the paddock and the impalas which continued to graze the paddock throughout the experiment (Horak 1981; Soulsby 1968).

The degree of infection established in the goats in the present study was low as noted both by the faecal egg counts and by nematode recovery (Hansen \& Perry 1994). While the unusually dry weather during November 2002 was most probably detrimental to the survival of Haemonchus larvae on the pasture, the grazing area was probably too large, relative to the number of goats grazed on it, to allow adequate infection of the pasture for the experiment. The infection of the goats could probably have been exacerbated by establishing a heavy infection on the pasture by grazing small ruminants on it for 1-2 years before the experiment, by using a trickle infection to infect the goats (Barger, Le Jambre, Georgi \& Davies 1985), and by utilizing a pasture with fewer or no browse species in order to encourage the goats to graze.

The general finding in this study was that since the parasite burdens were low, the tactical treatment of the gastrointestinal nematode infections had no significant effect on the production parameters of the goats but that the nutritional factors probably had a relatively bigger impact.

The paddocks where the goats grazed can best be described within Acocks's (1988) classification as Other Turf Thornveld, specifically Norite Black Turfveld. These paddocks had a range of bush species available, which the goats were assumed to have browsed throughout the year. The availability of these browse species in the herbage may have accounted for the fact that the acid detergent fibre and neutral detergent content of the herbage remained relatively consistent throughout the year. As is to be expected, the dry matter and crude protein of the herbage varied with the seasons, being lowest and highest, respectively, during the wet summer period (Table 4). During the winter period, the dry matter was highest and the crude protein lowest. The serum urea values gave an immediate indication of the availability of crude protein in the pasture as it was highest during the summer period and lowest during the winter and subsequent spring. The serum albumin and body condition scores also reflected the availability of crude protein in the pasture, but there was a lag period before a change became evident. For example, highest values of crude protein recorded in the summer period were only reflected in highest values for albumin and body condition scores in the autumn. Although the mean haematocrits were at the lower end of the haematocrit range for goats as given by Feldman et al. (2000), the values are similar to normal values reported for goats 1-2 years old from India (22.6\%) and Nigeria $(26.9 \pm 3.8 \%)$, but lower than values reported for adult wethers from the UK $(34.8 \pm 3.8 \%)$ and adult goats from the United States $(34.0 \pm 4.9 \%)$ (Smith \& Sherman 1994).

The crude protein content of the herbage during summer was probably sufficient to fulfil the goats' growth needs, as shown by increasing body condition scores during this period. As such, any additional urea intake will have been inefficiently utilized and lost in the urine. In the winter, however, the crude protein of the herbage had declined and there was an apparent shortage of dietary crude protein as evidenced by a decrease in body condition and in low serum-urea levels. As a result, supplementation of the goats during this period was beneficial. However, intake of the urea-molasses blocks was low. The reasons for this are unclear, but an improved intake of the blocks may have resulted in a better effect on the growth of the goats and the resultant dressed-out carcass masses.

An alternative to urea-molasses block supplementation for parasitized ruminants is the use of bypass protein which is found in the by-products of vegetable oil extraction, i.e. oil cake meals. Magaya, Mukaratirwa, Willingham, Kyvsgaard \& Thamsborg (2000) showed a beneficial effect of cottonseed meal supplement with or without anthelmintic treatment on growth performance of parasitized weaner steers in 
Zimbabwe. Supplementation of ruminants with oil cake meal tends to be expensive and researchers have thus examined the use of locally available sources of protein as dry-season supplements, including leguminous browse species and their pods (Aganga \& Wani 1998; Sikosana, Smith, Mlambo, Owen, Mueller-Harvey, Mould \& Maphosa 2004). Harvesting of the leaves and pods of such leguminous plants may be feasible on a sustainable basis in areas of the summer rainfall area of southern Africa where they occur.

The cost-benefit analysis of the present study, nevertheless, indicated that dry-season winter supplementation of Boer goats with urea-molasses blocks from June to August without tactical anthelmintic treatment, was associated with a $6 \%$ increase in carcass value over the corresponding controls. This equated to US\$ 3.30 per animal which is considered economically viable and worthwhile.

\section{ACKNOWLEDGEMENTS}

Dr R.L. Coop, formerly of the Moredun Research Institute, Scotland, is thanked for his scientific input to the study and Messrs M.D. Chipana, R.F. Masubelle, M.W. Shima and M.L. Tshikhudo and Ms L.M. Michael of the OVI, South Africa for their technical assistance. Dr J.A. van Wyk supplied the third-stage nematode larvae to the OVI larval bank and Mr L.J. van Rensburg assisted in preparing the larvae for infection of the goats. The Division of Toxicology is thanked for assistance with the drying and milling of the feed samples. The ARC-Irene Analytical Services, especially Ms J. Collier, are gratefully acknowledged for carrying out the feed analyses. Ms L. Morey, ARC Biometry Unit, South Africa is gratefully acknowledged for assistance with the initial processing of the data. Prof. F. Rijkenberg is thanked for useful comments on the manuscript. This paper is an output from Project R8151 funded by the Animal Health Programme of the UK Government Department for International Development (DFID), for the benefit of developing countries. The views expressed are not necessarily those of DFID. The project was also supported financially by a DFID British Council Higher Education Link between the University of Edinburgh and the University of Pretoria (JHB/17/ 2003), as well as a Royal Society (UK)/National Research Foundation (South Africa) Science Networking agreement. Any opinions, findings, conclusions or recommendations expressed in this material are those of the authors and therefore the National Research Foundation does not accept any liability in regard thereto. The South African Weather
Service is acknowledged for supplying the temperature data.

\section{REFERENCES}

ACOCKS, J.P.H. 1988. Veld types of South Africa, $3^{\text {rd }}$ ed. Botanical Research Institute, Department of Agriculture and Water Supply, South Africa (Memoirs of the Botanical Survey of South Africa No. 57)

AGANGA, A.A. \& WANI, M. 1998. Dichrostachys cinerea and Acacia nilotica as supplements to buffalo grass (Buchloe dactyloides) hay fed to Tswana goats. Bulletin of Animal Health and Production in Africa, 46:167-170.

BARGER, I.A., LE JAMBRE, L.F., GEORGI, J.R. \& DAVIES, H. I. 1985. Regulation of Haemonchus contortus populations in sheep exposed to continuous infection. International Journal for Parasitology, 15:529-533.

BOOMKER, J., HORAK, I.G. \& RAMSAY, K.A. 1994. Helminth and arthropod parasites of indigenous goats in the northern Transvaal. Onderstepoort Journal of Veterinary Research, 61:13-20.

COOP, R.L. \& KYRIAZAKIS, I. 1999. Nutrition-parasite interaction. Veterinary Parasitology, 84:187-204.

FELDMAN, B.V., ZINKL, J.G. \& JAIN, N.C. 2000. Schalm's veterinary haematology, $5^{\text {th }}$ ed. Baltimore: Lippincott Williams and Wilkins.

GOERING, H.K. \& VAN SOEST, P.J. 1970. Forage fiber analyses (apparatus, reagents, procedures and some applications). USDA-ARS Agricultural Handbook No. 379. Washington, DC: US Government Printing Office.

HANSEN, J. \& PERRY, B. 1994. The epidemiology, diagnosis and control of helminth parasites of ruminants. A handbook. Nairobi: International Laboratory for Research on Animal Diseases (now International Livestock Research Institute).

HARRIS, L.E. 1970. Nutrition research techniques for domestic and wild animals. Vol 1. Logan: Utah State University.

HORAK, I.G. 1978. Parasites of domestic and wild animals in South Africa. V. Helminths in sheep on dryland pasture on the Transvaal Highveld. Onderstepoort Journal of Veterinary Research, 45:1-6.

HORAK, I.G. 1981. Host specificity and the distribution of the helminth parasites of sheep, cattle, impala and blesbok according to climate. Journal of the South African Veterinary Association, 52:201-206.

HORAK, I.G. \& LOUW, J.P. 1977. Parasites of domestic and wild animals in South Africa. IV. Helminths in sheep on irrigated pasture on the Transvaal Highveld. Onderstepoort Journal of Veterinary Research, 44:261-270.

MAGAYA, A., MUKARATIRWA, S., WILLINGHAM, A.L., KYVSGAARD, N. \& THAMSBORG, S. 2000. Effects of anthelmintic treatment and feed supplementation on grazing Tuli weaner steers naturally infected with gastrointestinal nematodes. Journal of the South African Veterinary Association, 71:31-37.

PERRY, B.D., RANDOLPH, T.F., MCDERMOTT, J.J., SONES, K.R. \& THORNTON, P.K. 2002. Investing in animal health research to alleviate poverty. Nairobi: International Livestock Research Institute.

REINECKE, R.K. 1983. Veterinary helminthology. Durban: Butterworths.

ROBERTSON, J.B. \& VAN SOEST, P.J. 1981. The detergent system of analysis and its application to human foods, in The 
analysis of dietary fiber in food, edited by W.P.T. James \& O. Theander. New York: Marcel Dekker.

SIKOSANA, J.L.N., SMITH, T., MLAMBO, V., OWEN, E., MUELLER-HARVEY, I., MOULD, F. \& MAPHOSA, V. 2004. Supplementation of on-farm goats using feed resources available in south-west Zimbabwe, in The contribution of small ruminants in alleviating poverty: communicating messages from research. Proceedings of the third DFID Livestock Production Programme link project (R7798) workshop for small ruminant keepers. Izaak Walton Inn, Embu, Kenya, 4-7 February 2003, edited by T. Smith, S.H. Godfrey, P.J. Buttery \& E. Owen. Aylesford: Natural Resources International Ltd: 139-143.

SMITH, D.G. 1999. The impact of grazing time allowance on the dry matter intake and foraging behaviour of cattle and donkeys managed under traditional African grazing systems. Ph.D. thesis, University of Edinburgh.

SMITH, M.C. \& SHERMAN, D.M. 1994. Goat medicine. Baltimore: Lippincott Williams and Wilkins.

SOULSBY, E.J.L. 1968. Helminths, arthropods and protozoa of domesticated animals, $6^{\text {th }}$ ed. of Mönnig's veterinary helminthology and entomology. London: Baillière, Tindall and Cassell.

VAN SCHALKWYK, P.C., SCHRÖDER, J., MALAN, F.S. \& VAN WYK, J.A. 1995. Worm Workshop Recommendations on Worm Control, $1^{\text {st }}$ rev. Pretoria: Onderstepoort Veterinary Institute.

VAN WYK, J.A., CABARET, J. \& MICHAEL, L.M. 2004. Morphological identification of nematode larvae of small ruminants and cattle simplified. Veterinary Parasitology, 119:277-306.
VAN WYK, J.A., SCHRÖDER, J., VAN SCHALKWYK, P.C. \& HORAK, I.G. 1987. Tegnieke: Helmintologie, in Proceedings of the Worm Resistance Workshop, Onderstepoort, Pretoria, 24-25 August 1987, edited by J. Schröder. Pretoria: Veterinary Research Institute Onderstepoort and South African Veterinary Association: 119-140.

VATTA, A.F. 2001. Incidence, clinical appraisal and treatment of haemonchosis in small ruminants of resource-poor areas in South Africa. M.Sc. dissertation, University of Pretoria.

VATTA, A.F., LETTY, B.A., VAN DER LINDE, M.J., VAN WIJK, E.F., HANSEN, J.W. \& KRECEK, R.C. 2001. Testing for clinical anaemia caused by Haemonchus spp. in goats farmed under resource-poor conditions in South Africa using an eye colour chart developed for sheep. Veterinary Parasitology, 99:1-14.

VISSER, EVELYN L., VAN WYK, J.A. \& ALVES, REGINA M.R. 1987. Die identifikasie van die belangrikste nematode, in Proceedings of the Worm Resistance Workshop, Onderstepoort, Pretoria, 24-25 August 1987, edited by J. Schröder. Pretoria: Veterinary Research Institute Onderstepoort and South African Veterinary Association: 141-152.

WOOD, I.B., AMARAL, N.K., BAIRDEN, K., DUNCAN, J.L., KASSAI, T., MALONE, J.B., Jr, PANKAVICH, J.A., REINECKE, R.K., SLOCOMBE, O., TAYLOR, S.M. \& VERCRUYSSE, J. 1995. World Association for the Advancement of Veterinary Parasitology (W.A.A.V.P.) second edition of guidelines for evaluating the efficacy of anthelmintics in ruminants (bovine, ovine, caprine). Veterinary Parasitology, 58:181-213. 